\title{
$\gamma$-アミノ酪酸高含有カボチャ加工品製造と そのラット血圧上昇抑制作用
}

鵜澤昌好, 奥山知子, 村田真由美, 佐藤良二, 大森正司*

\author{
Development of Manufacturing Process of Squash Products Rich in \\ $\gamma$-Aminobutyric Acid, and an Effect of the Products \\ on the Blood Pressure of Spontaneously \\ Hypertensive Rats
}

\author{
Masayoshi Uzawa, Satoko Okuyama, Mayumi Murata, Ryoji Sato and Masashi Omori* \\ Central Laboratory, LOTTE Co., LTD., 3-1-1, Numakage, Saitama-shi, Saitama 336-8601 \\ * Faculty of Home Economics, Otuma Women's University, 12, Sanbancho, Chiyoda-ku, Tokyo 102-8357
}

\begin{abstract}
Glutamate decarboxylase (GAD : EC 4.1.1.15) exists widely in animals and plants, and it is contained much specially in animal's brain and in higher plants such as squash, carrot, and tomato. We found that the activity of squash GAD was the strongest in these plants. So we investigated about various nature of squash GAD in order to transform L-glutamic acid into $\gamma$-aminobutyric acid by using squash. In this study, it was found that reaction conditions of GAD and coenzyme, pyridoxal 5'-phosphate influenced on progress of L-glutamic acid transformation in squash. We examined the reaction conditions to make the transformation enough. Consequently, we found the best range of $\mathrm{pH}$ value, temperature, and the amount of L-glutamic acid for entire transformation using the activity of squash GAD fully. And we established the techniques of manufacturing squash products containing much $\gamma$-aminobutyric acid from squash with L-glutamic acid, or squash with casein hydrolysate containing L-glutamic acid. Furthermore, we confirmed an effect on the blood pressure of spontaneously hypertensive rats of the products manufactured with these techniques.
\end{abstract}

(Received Nóv. 2, 2001 ; Accepted Jun. 25, 2002)

$r-ア ミ ノ$ 酪酸は GABA 之略称され, 神経抑制作用, 精 神安定などの機能を有していることがわかっている.さ らに, 血圧降下作用"), 脳の新陳代謝促進作用 ${ }^{2)}$, 精神安 定作用 ${ }^{3)}$, 腎機能改善作用等(4) に効果がある物質として 6近年注目され始めている.

食品中の $\gamma-ア ミ ノ$ 酪酸を增強した食品としては, 1987 年に農林水産省野菜・茶業試験場が，茶葉を嫌気的に処 理して得た茶を「ギャバロン茶」として開発している5). この「ギャバロン茶」の $\gamma$-アミノ酪酸含有量は乾燥茶葉 $100 \mathrm{~g}$ 中 $100 \mathrm{mg}$ 以上之, 通常の茶の $10 \sim 30 \mathrm{mg} / 100 \mathrm{~g}$ K
比較して非常に多くなっている．また，米肧芽を加工す ることにより $\gamma-ア ミ ノ$ 酪酸含量を大幅に增加できること が知られており6), 米や米胚芽を水に浸漬して， $\gamma$-アミ 八酪酸を富化させる方法が開発されている゙．通常のコ シヒカリは $\gamma$-アミノ酪酸含量が $25-50 \mathrm{mg} / 100 \mathrm{~g}$ 程度で あるが,この方法で処理した結果, $r$-アミノ酪酸含有量 を約 10 倍に高めることができる ${ }^{8)}$.この他, $r$-アミノ酪 酸の含量を上げるために乳酸菌, 酵母, クロレラ, 趓な ど利用した $\gamma$-アミ，酪酸を高濃度含有する食品素材の 製造方法なども研究されている ${ }^{9100}$. 
$\gamma$ アアミノ酪酸はグルタミン酸脱炭酸酵素の働きで，グ ルタミン酸から生成されることが知られており, 市販の グルタミン酸脱炭酸酵素 (EC 4.1.1.15, Glutamate decarboxylase）を用いれば， $r-ア ミ /$ 酪酸高含有素材 の製造は簡単に達成されるが, 酵素の活性保持のために は食品に使用できない合成品のピリドキサル 5'ーりん酸 （以後 PLP 亡略）やメルカプトエタノールを添加する必 要があり，現実的には食品への利用は難しい.

このグルタミン酸脱炭酸酵菜は高等植物であるカボ チャ, ニンジンなどに存在しており ${ }^{11)}$, 生野菜の粉砕物 にグルタミン酸ナトリウムを混合して放置すれば $\gamma-ア$ ミ／酪酸を生産させることが可能であると考えられる が, 単純には $\gamma$-アミノ酪酸を高含有量にすることは出来 ていない，そこで本研究では, 野菜等の高等植物のグル 夕ミン酸脱炭酸酵素活性, 及び反応条件等を検討し, 緑 黄色野菜を原料として初めて $\gamma$-アミノ酪酸高含有素材 を開発し，また，その素材の血圧上昇抑制効果を確認し たので報告する.

\section{実 験 方 法}

\section{1. 各種野菜のグルタミン酸脱炭酸酳素活性測定法}

西洋力ボチャ (Cucurbita maxima Duch, 以後力ボ チャ上呼ぶ），キュウリ，ニンジン，ダイコン（以上市販 品を購入)をフードプロセッサーに約 10 秒間かけて約 1 $\mathrm{mm}$ 角以下になるまで粉研し，各 $5 \mathrm{~g} に 0.1 \%$ グルタ ン酸溶液 $10 \mathrm{ml}$ を加え， $40^{\circ} \mathrm{C}$ で 2 時間振とうした. 振と う前後の $\gamma-ア ミ /$ 酪酸含量をアミ／酸分析計（日本電子 JLC-300）を用いて測定し， $r-ア ミ /$ 酪酸生成量を算出 した.

\section{2. カボチャのグルタミン酸脱炭酸酵素の分画法 ${ }^{12)}$}

カボチャ $1 \mathrm{~kg}$ に $0.01 \mathrm{mMPLP}$ を含む $50 \mathrm{mM}$ りん酸 ナトリゥム緩衝液（pH $5.8:$ 以後 A 緩衝液之呼ぶ） $1.5 l$ を加えてフードプロセッサーに約 10 秒間かけて約 1 $\mathrm{mm}$ 角以下になるまで粉砕後，ミキサーに約 15 秒かけ て液状にし，さらに乳鉢で摩砕し，遠心分離 $(10000 \times \mathrm{g}$, 20 分）した上清をろ過し，ろ液に A 緩衝液で平衡化さ せたイオン交換樹脂 (DEAE cellulose, 乾燥重量 $100 \mathrm{~g}$ ) を加えて $4^{\circ} \mathrm{C} 30$ 分間攪汼して吸着させ, $0.1 \mathrm{M}$ 塩化ナト リウムを含む $\mathrm{A}$ 緩衝液 $1 l$ で樹脂を洗浄後, $0.3 \mathrm{M}$ 塩化ナ トリウムを含む $\mathrm{A}$ 緩衝液 $1 l$ で樹脂から溶出した. 溶出 液を $70 \%$ 飽和硫安沈殿させ, A 緩衝液で透析後, 透析膜 内液を凍結乾燥して粗酵素とした.

3. カボチャから抽出精製した粗醭素の活性測定法

(1) グルタミン酸脱炭酸酵素活性測定法 ${ }^{12)}$
粗酵素 3-5 mg を冷水 $1 \mathrm{~m} l$ に溶解した粗醉素液 20$100 \mu l$ に $2 \mathrm{mMPLP} 100 \mu l$ を添加し, $0.1 \mathrm{M}$ りん酸ナト リゥム緩衝夜（pH 5.8）を加えて全容を $900 \mu l$ の反応液 とした．反応液を $40^{\circ} \mathrm{C}$ 湯浴中で $3-5$ 分間加熱 L, $0.2 \mathrm{M}$ グルタミン酸 $100 \mu l$ を加えて反応を開始し，1-20 分後 に $4 \mathrm{~N}$ 塩酸 $50 \mu l$ を添加して反応停止し, 反応液中の $\gamma-$ アミノ酪酸含量をアミ/酸分析計を用いて測定し，七ミ ミクロケルダール法で测定したタンパク質含量を用いて 比活性を算出した。

(2) 活性に及ぼす $\mathrm{B}_{6}$ 補酵素の影響

蒸留水 $50 \mathrm{~m} l$ に粗酵素 $100 \mathrm{mg}$, PLP $12.3 \mathrm{mg}$ または塩 酸ピリドキシン $9.5 \mathrm{mg}$ を添加して， $40^{\circ} \mathrm{C}$ 湯浴中で加熱 し，グルタミン酸 $1 \mathrm{~g}$ を加えて反応を開始させ，24 時間 攪拌後の反応液中のグルタミン酸量, $\gamma-ア ミ /$ 酪酸量を アミノ酸分析計を用いて测定した。

4. カボチャ粉砕液を使用したグルタミン酸変換反応 効率化の検討

(1) カボチャ粉砕液調製法

カボチャの種子を除去し，蒸留水を加えてフードプロ セッサーに約 10 秒間かけて約 $1 \mathrm{~mm}$ 角以下になるまで 粉砕後, ミキサーに約 15 秒かけて液状にし粉砕液とし た。

（2）カボチャ粉砕液を利用したグルタミン酸変換反応 に対する $\mathrm{pH}$, 温度条件の検討

カボチャ粉砕液（カボチャ $20 \mathrm{~g}$, 蒸留水 $40 \mathrm{ml}$ を含む) にグルタミン酸 $1 \mathrm{~g}$ を添加して摫拌しながら，0.3 $\mathrm{N}$ 塩酸 を滴下して $\mathrm{pH}$ を一定に保持し（pH スタット法）, 温度 一定にて 16 時間変換反応を行なった.

（3）カボチャ粉研液を利用したグルタミン酸変換反応 における基質添加量の検討

カボチャ粉砕液 (カボチャ $15 \mathrm{~g}$ ，蒸留水 $50 \mathrm{ml}$ を含む)

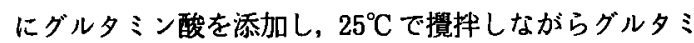
ン酸全てが $\gamma-ア ミ /$ 酪酸に変換するまで長時間変換反 応を行なった。

(4)）カボチャ粉砕液を利用したグルタミン酸変換反応 における基質添加法の検討

i）一括添加法

カボチャ粉砕液（カボチャ $150 \mathrm{~g}$, 蒸留水 $500 \mathrm{~m} l$ を含 む)にグルタミン酸 $15 \mathrm{~g}$ を添加して室温 $\left(25 \pm 1^{\circ} \mathrm{C}\right)$ で摫 拌した。

ii） 分割添加法

カボチャ粉砕液（カボチャ $150 \mathrm{~g}$, 蒸留水 $500 \mathrm{ml}$ を含 む）にグルタミン酸 $1 \mathrm{~g}$ を添加して室温 $\left(25 \pm 1{ }^{\circ} \mathrm{C}\right)$ で靦 找し，グルタミン酸の添加により低下した $\mathrm{pH}$ が 6.0 ま 
で上昇してから，次の $1 \mathrm{~g}$ を添加したこれを15回繰り 返して合計 $15 \mathrm{~g}$ のグルタミン酸を添加した. グルタミン 酸を最初に添加した時点をスタートとし, 最後にグルタ ミン酸を添加した後 $\gamma-$ アミ/酪酸の生成によりカボ チャ粉砕液の $\mathrm{pH}$ が 6.2 に上昇するまでの時間を反応時 間とした。

（5）反応後のカボチャ㸮研液加らの水溶性成分分画法 反応後のカボチャ粉碎液を遠心分離 $(2,200 \times \mathrm{g}, 10$ 分 間）して固形分を除去した上清を加熱後，不溶物を滤別 （滤紙，ADVANTEC No.1）して凍結乾燥した。 なお，

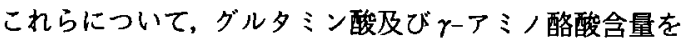
アミノ酸分析計を用いて測定した。

5. グルタミン酸供給源としてカゼイン加水分解物を 使用した $\gamma$ ーアミノ酪酸高含有素村調製の検討

カボチャ粉研液（カボ千ャ $150 \mathrm{~g}$, 蒸留水 $400 \mathrm{~m} l$ ) を含 む）を摬找し，カゼイン加水分解物 $50 \mathrm{~g}$ （カゼインを塩 酸で加水分解したグルタミン酸約 20\% 含有するもので 成分組成を Table 1 に示吉）を一度に添加して, pH ス タット法 (1N 塩酸使用) により $\mathrm{pH}$ を5.8に保持しなが ら室温 $\left(25 \pm 1{ }^{\circ} \mathrm{C}\right)$ にて 16 時間変換反応を行なった。

6. $\boldsymbol{r}$-アミノ酪酸高含有素材の血圧上昇抑制効果試験

(1) 試 料

i）カボチャ加工品 I

カボチャ粉砕液（カボチャ $1500 \mathrm{~g}$, 蒸留水 $4.5 \mathrm{l}$ を含 む）にグルタミン酸 $150 \mathrm{~g}$ を分割して添加して筧拌し， 室温 $\left(25 \pm 1^{\circ} \mathrm{C}\right)$ にて一定時間保持して,グルタミン酸の

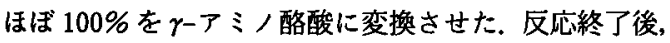

反応液を遠心分離した上清液の加熱処理を行ない，ろ過 後，ろ液にデキストリンを加えて噴霧乾燥した。

ii）力ボチャ加工品II

カボチャ粉碎液（カボチャ $2500 \mathrm{~g}$ ，蒸留水 $4 l$ を含む） に，'力ゼイン加水分解物 $400 \mathrm{~g}$ を添加して筧拌し，室温 $\left(25 \pm 1^{\circ} \mathrm{C}\right)$ で $\mathrm{pH}$ スタット法により $\mathrm{pH}$ を 5.8 に一定時 間保持して,グルタミン酸のほぼ $100 \%$ そーアミノ酪酸 に変換した，反応終了後反応液を遠心分離した上清液の 加熱処理を行ない，万過したろ液を凍結乾燥した。

iii）カボチャ加工品 III

カボチャ粉碎液（カボチャ $1250 \mathrm{~g}$, 蒸留水 $2 l$ を含む) を $95^{\circ} \mathrm{C}$ 以上まで加熱した後，カゼイン加水分解物 $200 \mathrm{~g}$ を添加して溶解した。これを再び加熱処理し，遠心分離 した上清液をろ過したろ液を凍結乾燥した。

各カボチャ加工品の組成を Table 1 に示した.

(2) 動物実験

i）食塩負荷条件による血圧上昇抑制試験（食塩負荷 加速試験)

高血圧自然発症ラット（以降 SHR 系ラットと呼称） 雄 4 週齢 $(140 \sim 160 \mathrm{~g})$ を星野動物飼育所より購入し, 日 本クレア製 $\mathrm{CE}-2$ を投与して予備飼育を行なった． 2 週 間の予備飼育後， 6 週歯において，各群の血圧の平均値 が同じになるように，1群6匹として4 群に分けた，1群 には対照区として粉末 CE-2 の 5\%セルロース含有飼料 之飲料水を, 2 群には粉末 $\mathrm{CE}-2$ の $5 \%$ 食塩含有飼料之 飲料水を， $3 ， 4$ 群には粉末 $\mathrm{CE}-2$ の $5 \%$ 食塩含有飼料と カボチャ加工品 $\mathrm{I}, I I の 0.5 \%$ 水溶液をそれぞれ供与し，

Table 1 Composition of casein hydrolysate and squash products

\begin{tabular}{|c|c|c|c|c|c|c|c|c|c|}
\hline & \multirow[b]{2}{*}{$\begin{array}{c}\text { Energy } \\
\text { (kcal/ } \\
100 \mathrm{~g})\end{array}$} & \multirow[b]{2}{*}{$\begin{array}{l}\text { Water } \\
(\mathrm{g} / 100 \mathrm{~g})\end{array}$} & \multicolumn{3}{|c|}{ Protein* } & \multirow[b]{2}{*}{$\underset{(\mathrm{g} / 100 \mathrm{~g})}{\mathrm{Fat}}$} & \multirow[b]{2}{*}{$\begin{array}{c}\text { Carbo- } \\
\text { hydrates } \\
(\mathrm{g} / 100 \mathrm{~g})\end{array}$} & \multicolumn{2}{|c|}{ Minerals } \\
\hline & & & $\begin{array}{c}\text { Total } \\
(\mathrm{g} / 100 \mathrm{~g})\end{array}$ & $\begin{array}{c}\gamma \text {-Amino- } \\
\text { butyric } \\
\text { acid } \\
(\mathrm{g} / 100 \mathrm{~g})\end{array}$ & $\begin{array}{c}\text { L-gluta- } \\
\text { mic } \\
\text { acid } \\
(\mathrm{g} / 100 \mathrm{~g})\end{array}$ & & & $\begin{array}{c}\text { Total } \\
(\mathrm{g} / 100 \mathrm{~g})\end{array}$ & $\underset{(\mathrm{mg} / 100 \mathrm{~g})}{\text { Sodium }}$ \\
\hline $\begin{array}{l}\text { Casein } \\
\text { hydrolysate }\end{array}$ & 344 & 3.7 & 82.9 & 0.0 & 20.4 & 0.1 & 2.8 & 10.5 & 5400 \\
\hline \multicolumn{10}{|c|}{ Squash products } \\
\hline Sample I & 384 & 2.3 & 12.1 & 10.0 & 0.0 & 0.0 & 83.9 & 1.7 & 25 \\
\hline Sample II & 324 & 6.0 & 61.0 & 10.0 & 0.5 & 0.0 & 20.0 & 13.0 & 2218 \\
\hline Sample III & 322 & 4.8 & 60.5 & 0.2 & 0.5 & 0.0 & 20.0 & 12.5 & 2035 \\
\hline
\end{tabular}

Casein hydrolysate was made from casein by acid hydrolysis. Sample I was made by the reaction of squash and L-glutamic acid mixture, and $\gamma$-aminobutyric acid contents was adjusted to $10 \%$ by the addition of the dextrin solution. Sample II was made by the reaction of squash and L-glutamic acid mixture, and $r$-aminobutyric acid contents was adjusted to $10 \%$ by the casein hydrolysate. Sample III was made from sterilized squash and casein hydrolysate mixture. *Protein contains free amino acids. 
Table 2 The amount of $\boldsymbol{\gamma}$-aminobutyric acid formed by glutamate decarboxylase in various vegetables

\begin{tabular}{|c|c|c|c|}
\hline \multirow[b]{2}{*}{ Vegetables } & \multicolumn{3}{|c|}{$\gamma$-Aminobutyric acid $(\mathrm{mg} / 100 \mathrm{~m} l)$} \\
\hline & Before incubation $^{a}$ & After incubation ${ }^{b}$ & Amount formed ${ }^{b \cdot a}$ \\
\hline Squash & 18.2 & 72.5 & 54.3 \\
\hline Cucumber & 4.9 & 63.3 & 58.4 \\
\hline Carrot & 20.1 & 25.5 & 5.4 \\
\hline Radish & 10.4 & 20.7 & 10.3 \\
\hline
\end{tabular}

Homogenates of vegetables were incubated in $0.1 \%$ L-glutamic acid solution for 2 hours at $40^{\circ} \mathrm{C}$. $\gamma$-Aminobutyric acid in the solution was measured using an amino acid analyzer.

自由摄取とした.ラットは個別ケージを用いて温度 $22 \pm$ $2{ }^{\circ} \mathrm{C}$, 湿度 $55 \pm 2 \%, 1$ 日 12 時間の昼夜サイクル下の空調 動物室で飼育した。

試験期間は 6 週齢から 10 週齢（約 1 ケ月）までとし， 血圧変化を測定した。.また毎週 1 回, 体重, 飲料量, 血 圧の測定を行なった，血圧測定はラット尾静脈でのプレ チモグラフィーを応用したテイルカフ法で行なった．测 定にはヴェダアヴァンセ(株) 製プレチモ式ラット血压 計 UR・5000を用いた。観察終了後屠殺解剖し, 臓器所 見, 臓器重量測定, 臟器アミノ酸分析を行なった。

ii）血圧上昇抑制試験

SHR 系雄ラット5 週齢 $(140 \sim 160 \mathrm{~g})$ を星野動物飼育 所より購入し，日本クレア製 CE-2 投与して予備飼育 を行なった. 2 週間の予備飼育後, 7 週齢において各群の 血圧の平均值が同じになるように， 1 群 5 匹ずつ 3 群に 分けた. 1 群には飲料水を, 2 群にはカボチャ加工品Iの $0.1 \%$ 溶液を， 3 群には力ボチャ加工品正0. $1 \%$ 溶液を供 与し，それぞれ自由撕取とした. ラットは個別ケージを 用いて温度 $22 \pm 2{ }^{\circ} \mathrm{C}$, 湿度 $55 \pm 2 \%, 1$ 日 12 時間の尽夜 サイクル下の空調動物室で飼育した.

試験期間は 7 週齢から 15 週齢（約 2 ケ月）までとし， 血圧変化を测定した. 体重, 飲料量, 血圧の測定はｉ）上 同様に行ない, 観察終了後, 屠殺解剖し, 歲器所見, 臹 器重量測定，測定は蔵器アミノ酸の分析を行なった。 ま た，この実験計画及び実施にあたっては，“実験動物の飼 育及び保管等に関する基準”13) 遵守して行なった.

\section{実験結果及び考察}

\section{1. 各種野菜のグルタミン酸脱炭酸酵素活性の此較}

グルタミン酸脱炭酸酵菜は高等植物の野菜ではカボ チャ,キュウリ，ニンジン，ダイコン，トマトなどに多
く含まれる.そこでカボチャ,キュウリ，ニンジン，ダ イコンのグルタミン酸脱炭酸酵素活性を $\gamma-ア ミ /$ 酪酸 量生成量として測定し，Table 2 において結果を比較し た.カボチャ,キュウリの $\gamma-ア ミ ノ$ 酪酸生成量はニンジ ン, ダイコンよりも多く, 高いグルタミン酸脱炭酸酵素 活性を示した。

\section{2. カボチャのグルタミン酸脱炭酸酵素の性賈}

各種野菜と比較してグルタミン酸脱炭酸酵素活性が高

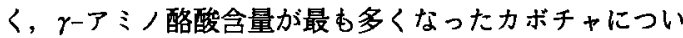
て粗酵素を抽出, 精製し，その性質を調べた。

（1）抽出酵素の性質

Table 3 に示すように，力ボチャ粉砕液を遠心分離し た上清である粗抽出液をイオン交換 DEAE Cellulose 処 理すると,グルタミン酸脱炭酸䣼素の比活性は 5.5 倍に, 透析・凍結乾燥後の粗酵素では 18 倍となった，粗醉素 の至適 $\mathrm{pH}$ は 5.8 , 至適温度は $60^{\circ} \mathrm{C}$ であり, 文献值と一 致した ${ }^{14)}$

（2）酵素反応時の補醉素の影響

カボチャのグルタミン酸脱炭酸醉素は補醳素として酵 素 1 分子当たり平均 3.8 分子の PLPを持つピリドキサ ル醉素であり， $\mathrm{pH}$ が高くなるとPLP が離脱し，酵素活 性が低下することが知られている ${ }^{12)}$.

今回抽出した粗酵素も，抽出操作で補醉素が一部離脱 したと思われ，酵素反応の際には補酵素を添加しなけれ ば酵素活性は低かった．グルタミン酸脱炭酸酵素を食品 に加えて, 食品中の $\gamma-ア ミ ノ$ 酪酸含量を増加させるため には，酵素活性を維持しなければならないが，食品の製 造には食品や食品添加物以外は使用できない，そのた め, 添加する補酵素として，食品添加物として許可され ていない PLP の代わりに，食品添加物である塩酸ピリ ドキシンが使用できないかどうかを検討した. 
Table 3 Summary of purification of squash glutamate decarboxylase

\begin{tabular}{lccccc}
\hline Purification step & $\begin{array}{c}\text { Total protein } \\
\text { (mg) }\end{array}$ & $\begin{array}{c}\text { Total activity } \\
\text { (units) }\end{array}$ & $\begin{array}{c}\text { Yield } \\
(\%)\end{array}$ & $\begin{array}{c}\text { Specific activity } \\
\text { (units/mg protein) }\end{array}$ & $\begin{array}{c}\text { Purification } \\
\text { (fold) }\end{array}$ \\
\hline Crude extract & 12505 & 3155 & 100.0 & 0.25 & 1.0 \\
DEAE-cellulose & 861 & 1183 & 37.5 & 1.37 & 5.5 \\
treatment fraction & 147 & 673 & 21.3 & 4.58 & 18.2 \\
Crude enzyme & & & & & \\
\hline
\end{tabular}

Glutamate decarboxylase activity was assayed by measuring $\gamma$-aminobutyric acid using an amino acid analyzer. The reaction mixture contained $70-78 \mathrm{mM}$ phosphate buffer, pH 5.8,20 mM L-glutamic acid, $0.2 \mathrm{mM}$ pyridoxal $5^{\prime}$-phosphate, and enzyme solution in a final volume of $1.0 \mathrm{~m} l$. The mixture was incubated at $40^{\circ} \mathrm{C}$. Enzyme unit was defined as micromoles of $\gamma$-aminobutyric acid produced per 1 min.

カボチャから抽出した粗酵素をPLPまたは塩酸ピリ ドキシンとともにインキュベートして，グルタミン酸を 添加して酵素反応を行ない, 24 時間後のグルタミン酸量 および $\gamma-ア ミ ノ$ 酪酸量を測定して酵素活性を比較した. その結果, Table 4 に示すように, 塩酸ピリドキシン添 加時のグルタミン酸量は PLP 添加時と比較して多く, 一方塩酸ピリドキシン添加時の $\gamma-ア ミ ノ$ 酪酸量は, PLP 添加時より少なかった.このように PLP 添加では, グル タミン酸が $\gamma-ア ミ ノ$ 酪酸に変換されたが, 塩酸ピリドキ シン添加ではグルタミン酸はほとんど $\gamma$-アミ，酪酸に 変換されずに残存しており，䤃素活性は低かった：この ことから, 酵素活性を維持するためには $\mathrm{B}_{6}$ 補醉素が必 要であるが, その補酵素形は PLPであり, 塩酸ピリドキ シンでは代用できないことが分かった。このことは, データは示していないが, カボチャ粉㸴液から残渣を遠 心除去した抽出液を用いてグルタミン酸の変換反応を行 なった場合も同様であり，PLPを添加することにより $\gamma$-アミノ酪酸生成量は増加したが, 塩酸ピリドキシンで は変化しなかった。

これらの結果から, カボチャから抽出したグルタミン 酸脱炭酸酵素に, 補酵素として塩酸ピリドキシンを添加 して $\gamma$ ーアミノ酪酸高含有素材を製造することはできな いことがわかり，力ボチャ中の PLPを保持してグルタ ミン酸の変換反応を行なう条件を検討した.

\section{3. カボチャ粉砕液を使用したグルタミン酸変換反応} 効率化の検討

(1) $\mathrm{pH}$ スタット法により測定したカボチャ粉砕液の 至適 $\mathrm{pH}$

粗酵素液では酵素反応の至適 $\mathrm{pH}$ は 5.8 であったが, カボチャ粉砕液を使用してグルタミン酸を $\gamma-ア ミ ノ$ 酪 酸に変換する場合の,グルタミン酸変換率 $(\gamma-ア ミ)$ 酪
Table 4 Effect of vitamins on the amount of L-glutamic acid and $\gamma$-aminobutyric acid after the enzyme reaction

\begin{tabular}{|c|c|}
\hline $\begin{array}{c}\text { L-Glutamic acid } \\
(\mathrm{mg})\end{array}$ & $\begin{array}{c}\gamma \text {-Aminobutyric } \\
\text { acid (mg) }\end{array}$ \\
\hline $\begin{array}{l}\text { Pyridoxal } \\
\text { 5'-phosphate }\end{array}$ & 709 \\
\hline $\begin{array}{l}\text { Pyridoxine } \\
\text { hydrochloride }\end{array}$ & 168 \\
\hline $\begin{array}{l}\text { The reaction mixture conta } \\
\text { distilled water, } 100 \mathrm{mg} \text { of crud } \\
12.3 \mathrm{mg} \text { of pyridoxal } 5 \text {-phospha } \\
\text { pyridoxine hydrochloride. } \\
\text { incubated at } 40^{\circ} \mathrm{C} \text {, and the react } \\
\text { addition of } 1 \mathrm{~g} \text { of L-glutamic a } \\
\text { ture as a substrate. After } 24 \\
\text { mic acid and } \gamma \text {-aminobutyric a } \\
\text { ture were measured using an } \\
\text { lyzer. }\end{array}$ & $\begin{array}{l}\text { de enzyme, and } \\
\text { de } 50 \mathrm{ml} \text { of } \\
\text { ate or } 9.5 \mathrm{mg} \text { of } \\
\text { he mixture was } \\
\text { tion started after } \\
\text { acid to the mix- } \\
\text { hours, L-gluta- } \\
\text { acid in the mix- } \\
\text { amino acid ana- }\end{array}$ \\
\hline
\end{tabular}

酸生成量 $\times 100 / 反$ 応前のグルタミン酸全量から生成しう る $\gamma-ア ミ ノ$ 酪酸生成量) が最む高くなる至適 $\mathrm{pH}$ を室温 $\left(25 \pm 1^{\circ} \mathrm{C}\right)$ にて pH スタット法によって調へた。

Fig. 1 に示すように，カボチャ粉砕液によるグルタミ ン酸の $\gamma-$ ア 酪酸への変換率は, pH 5.7-5.9 で最も高 かった.

(2) 反応温度によるグルタミン酸変換率の違い

粗酵素液では酵素反応の至適温度は $60^{\circ} \mathrm{C}$ であったが, カボチャ粉砕液を使用してグルタミン酸を $\boldsymbol{\gamma}$ ーアミノ酪 酸に変換する場合の，グルタミン酸変換率が最も高くな る至適温度を調べた．反応中の $\mathrm{pH}$ は，力ボチャ粉砕液 によるグルタミン酸変換率が $\mathrm{pH}$ 5.7-5.9 で最む高かっ たため, pHスタット法により 5.8 に保持した. その結 


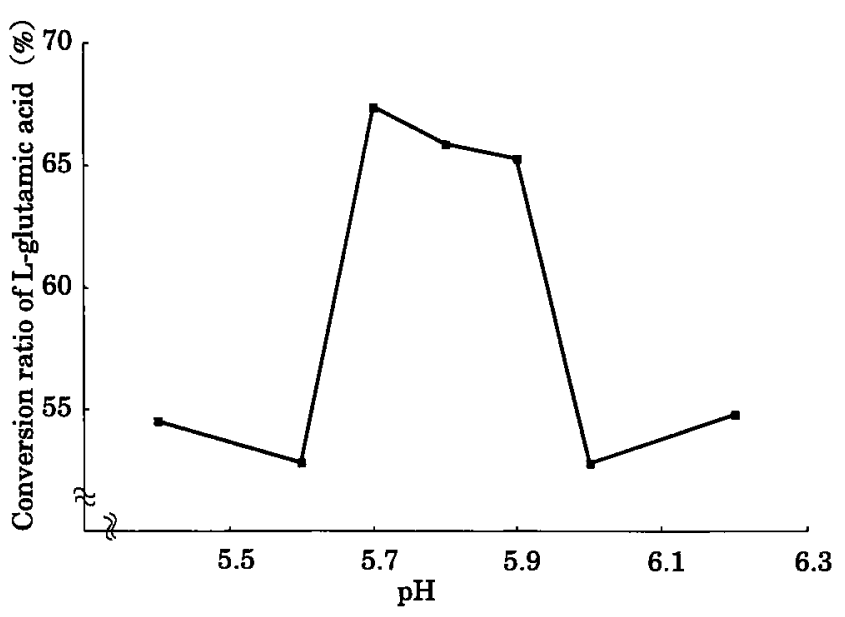

Fig. 1 Effect of $\mathrm{pH}$ value on the conversion ratio of L-glutamic acid

Twenty gram of crushed squash were incubated with $40 \mathrm{ml}$ of distilled water containing $1 \mathrm{~g}$ of L-glutamic acid for 16 hours at room temperature $\left(25 \pm 1^{\circ} \mathrm{C}\right)$. The incubation was performed at various $\mathrm{pH}$ value $(5.4,5.6,5.7,5.8,5.9,6.0,6.2)$ individually. The conversion ratio of L-glutamic acid was calculated by measuring $\gamma$-aminobutyric acid of the mixture using an amino acid analyzer.

Table 5 Effect of reaction temperature on the conversion ratio of L-glutamic acid

\begin{tabular}{cc}
\hline \hline Reaction temperature & $\begin{array}{c}\text { The conversion ratio of } \\
\text { L-glutamic acid (\%) }\end{array}$ \\
\hline $25^{\circ} \mathrm{C}$ & 46.2 \\
$30^{\circ} \mathrm{C}$ & 39.2 \\
$40^{\circ} \mathrm{C}$ & 20.8 \\
\hline
\end{tabular}

The reaction mixtures contained $40 \mathrm{~m} l$ of distilled water and $20 \mathrm{~g}$ of squash. The mixture was incubated at $25,30,40^{\circ} \mathrm{C}$ individually, and the reactions started after addition of $1 \mathrm{~g}$ of L-glutamic acid to the mixtures as substrate. The $\mathrm{pH}$ value of the mixtures were maintained at 5.8 by addition of $0.3 \mathrm{~N} \mathrm{HCl}$ during the reactions. After 16 hours, L-glutamic acid and $\gamma$-aminobutyric acid in the mixtures were measured using an amino acid analyzer, and the conversion ratio of L-glutamic acid was calculated.

\section{果, Table 5 に示すようにグルタミン酸変換率は反応温} 度が高くなるに従って低下した。

（3）基質 (グルタミン酸）添加量の検討

これまでの検討の結果, カボチャ粉砕液を使用した変 換反応におけるグルタミン酸変換率は， $\mathrm{pH}$ の保持, 反
応温度の調節によって向上することが分かった. カボ チャを利用して $\gamma$-アミノ酪酸高含有素材を製造するに 当って，一定量のカボチャがグルタミン酸をどれだけ $\gamma$ アミノ酪酸に変換可能であるか調べた. その結果, Table 6 に示すようにカボチャ $15 \mathrm{~g}$ に対してグルタミ ン酸を $1.0 \mathrm{~g}$ 添加した場合も，1.5 g 添加した場合むグル タミン酸変換率はほぼ $100 \%$ に達していた. また，反応 後のカボチャ粉砕液水溶性成分の凍結乾燥物中の $\gamma-\boldsymbol{\gamma}$ ミノ酪酸含量は,グルタミン酸を $1.0 \mathrm{~g}$ 添加した場合 $19.4 \% ， 1.5 \mathrm{~g}$ 添加した場合は $34.4 \%$ であった，しかし， グルタミン酸を $2.0 \mathrm{~g}$ 以上添加した場合は変換が不充分 (グルタミン酸変換率 $60 \%$ 未満) で, 反応後もグルタミ ン酸が残存していた.この結果から，15gのカボチャを 用いた場合, $1.5 \mathrm{~g}$ 以下のグルタ ンン酸は完全に $\gamma-ア ミ$ ノ酪酸に変換可能であることが分かった.

（4）基質添加法の検討

これまでの検討の結果, カボチャ粉砕液を使用してグ ルタミン酸の $r-ア ミ /$ 酪酸への変換反応を行なう場合, 反応液の $\mathrm{pH}$ を 5.7-5.9 に保持するよう $\mathrm{pH}$ 調整すると， 変換効率が高くなることが分かった. グルタミン酸添加 量が少ない場合は $\boldsymbol{\gamma}-ア ミ ノ$ 酪酸生成による $\mathrm{pH}$ の上昇 を抑えるために酸の滴下が必要であった，前項の検討に より，カボチャ $15 \mathrm{~g}$ に対してグルタミン酸を $1.5 \mathrm{~g}$ 添加 できることが分かったが，多量のグルタミン酸を一度に 
Table 6 Effect of the adding amount of L-glutamic acid on the concentration of $\gamma$-aminobutyric acid in squash product

\begin{tabular}{ccc}
\hline $\begin{array}{c}\text { The adding amount } \\
\text { of L-glutamic acid } \\
(\mathrm{g})\end{array}$ & $\begin{array}{c}\text { The conversion ratio } \\
\text { of L-glutamic acid } \\
(\%)\end{array}$ & $\begin{array}{c}\text { The concentration of } \\
\gamma \text {-Aminobutyric acid } \\
(\%)\end{array}$ \\
\hline 1.0 & 99.7 & 19.4 \\
1.5 & 99.8 & 34.4 \\
\hline
\end{tabular}

The reaction mixtures contained $50 \mathrm{~m} l$ of distilled water and $15 \mathrm{~g}$ of squash. The mixtures were incubated at $25^{\circ} \mathrm{C}$, and the reactions started after addition of $1 \mathrm{~g}$ of L-glutamic acid to the mixtures as substrate. After the reactions, the mixtures were centrifuged for $10 \mathrm{~min}$. at $2200 \times$ $\mathrm{g}$, and then the supernatants were freeze-dried. L-Glutamic acid and $\gamma$-aminobutyric acid in the dried supernatants were measured using an amino acid analyzer, and the conversion ratio of L-glutamic acid was calculated.

加えることによる $\mathrm{pH}$ の低下を緩和するため，水酸化ナ トリウム等のアルカリ溶液を滴下して $\mathrm{pH}$ 調整する必要 があった。しかし，塩の形成による製品の呈味への影響 と， $\gamma-ア ミ ノ$ 酪酸の血圧上昇抑制作用を検討する場合の ナトリゥムの阻害作用が問題と思われた，そこで, 酸を 滴下せず，基質であるグルタミン酸の添加方法を工夫す ることにより $\mathrm{pH}$ を調整する方法を検討した。

カボチャ粉砕液の $\mathrm{pH}$ は通常 7.0 付近であり, カボ チャ粉砕液にグルタミン酸を加えると溶液の $\mathrm{pH}$ は低下

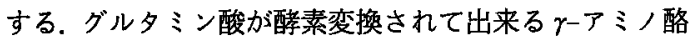
酸は弱アルカリ性のアミノ酸であるため, 変換反応の進 行に伴い $\mathrm{pH}$ は上昇する. $\mathrm{pH}$ が上昇したときにグルタ ミン酸を加えると $\mathrm{pH}$ は低下する．このようにグルタミ ン酸を少量ずつ添加することによって pH 調整が可能で あると考えられ，グルタミン酸による $\mathrm{pH}$ 調整を試み た.

なお,グルタミン酸は水への溶解度が低く, 水溶液と して添加するには多量の溶液を必要とするので粉体のま ま投入し，力ボチャ粉碎液中で摫汼しながら徐々に溶解 させた. また，グルタミン酸分割添加の場合，グルタミ ン酸を全量添加後も $\gamma$-アミノ酪酸が生成すると $\mathrm{pH}$ が 上昇するが，この時のカボチャ粉砕液の $\mathrm{pH}$ とグルタミ ン酸变換率の関係を調べた結果, $\mathrm{pH}$ が 6.2 以上でグル タミン酸はほぼ $100 \% \gamma-ア ミ ノ$ 酪酸に変換され，それ以 上 $\mathrm{pH}$ が上昇するまで復拌を続けてもグルタミン酸変換 率はほとんど変化しなかったことから， $\mathrm{pH}$ が 6.2 に なった時点で反応終了とした.

カボチャ $150 \mathrm{~g}$ 分のカボチャ粉砕液に，グルタミン酸
Table 7 Effect of the way of L-glutamic acid addition on the conversion ratio of L-glutamic acid

\begin{tabular}{lc}
\hline $\begin{array}{c}\text { The way of } \\
\text { L-glutamic acid } \\
\text { addition }\end{array}$ & $\begin{array}{c}\text { The conversion ratio } \\
\text { of L-glutamic acid } \\
(\%)\end{array}$ \\
\hline Addition collective & 24.6 \\
Addition in steps & 99.4 \\
\hline
\end{tabular}

The reaction mixtures contained $500 \mathrm{ml}$ of distilled water and $150 \mathrm{~g}$ of squash. The mixtures were incubated at room temperature $(25 \pm$ $1^{\circ} \mathrm{C}$ ), and the reactions started after the first addition of L-glutamic acid to the mixtures. After 17 hours, the mixtures were centrifuged for $10 \mathrm{~min}$. at $2200 \times \mathrm{g}$, and then the supernatants were freeze-dried. L-Glutamic acid and $\gamma$-aminobutyric acid in the dried supernatants were measured using an amino acid analyzer, and the conversion ratio of L-glutamic acid was calculated.

$15 \mathrm{~g}$ を $1 \mathrm{~g}$ ずつ分割して，pH 6.0 になる毎に加えてグル タミン酸変換反応を行なった結果, $\mathrm{pH}$ の低下は少なく, 最低でも 5.0 以上であった。また，グルタミン酸を全量 添加し終わってからカボチャ粉砕液の $\mathrm{pH}$ が 6.2 になる までの時間 (反応時間) は 17 時間であり,グルタミン酸 変換率は Table 7 に示すように 99.4\%であった. 一方， カボチャ $150 \mathrm{~g}$ 分の粉砕液に，グルタミン酸 $15 \mathrm{~g}$ を一度 に添加した場合は，pH が 4.0 以下に低下してほとんど 
Table 8 Effect of the squash products on the food intake, water intake and body weight gain of spontaneously hypertensive rats (SHR) dosed with $\mathrm{NaCl}$

\begin{tabular}{|c|c|c|c|c|c|}
\hline & \multirow{2}{*}{$\begin{array}{l}\text { Food } \\
\text { intake } \\
\text { (g/day) }\end{array}$} & \multirow{2}{*}{$\begin{array}{l}\text { Water } \\
\text { intake } \\
(\mathrm{m} l / \text { day })\end{array}$} & \multicolumn{2}{|c|}{ Body weight } & \multirow{2}{*}{$\underset{\text { (g/day) }}{\text { Gain }}$} \\
\hline & & & Initial $(\mathrm{g})$ & Final $(g)$ & \\
\hline \multicolumn{6}{|l|}{ i) SHR } \\
\hline Control rats (CE-2) & $20.9 \pm 3.1$ & $24.0 \pm 3.0$ & $226 \pm 10.1$ & $284 \pm 10.6$ & 2.1 \\
\hline $\mathrm{CE}-2$ containing $5 \% \mathrm{NaCl}$ & $21.0 \pm 2.2$ & $59.7 \pm 5.0^{*}$ & $236 \pm 8.6$ & $296 \pm 5.5$ & 2.1 \\
\hline CE- 2 containing $5 \% \mathrm{NaCl}$ and $0.5 \%$ sample I & $17.9 \pm 3.6$ & $50.0 \pm 8.9^{*}$ & $240 \pm 2.0$ & $300 \pm 6.8$ & 2.2 \\
\hline CE-2 containing $5 \% \mathrm{NaCl}$ and $0.5 \%$ sample II & $18.5 \pm 2.9$ & $42.9 \pm 6.8^{*}$ & $242 \pm 9.3$ & $299 \pm 7.9$ & 2.0 \\
\hline \multicolumn{6}{|l|}{ ii) SHR } \\
\hline Control rats (CE-2) & $19.5 \pm 3.0$ & $25.1 \pm 2.8$ & $158 \pm 7.5$ & $314 \pm 15.0$ & 2.8 \\
\hline CE- 2 and $0.1 \%$ sample II & $20.0 \pm 2.9$ & $23.9 \pm 3.1$ & $157 \pm 13.2$ & $307 \pm 16.5$ & 2.7 \\
\hline CE-2 and $0.1 \%$ sample III & $18.8 \pm 3.4$ & $24.2 \pm 3.5$ & $159 \pm 10.1$ & $308 \pm 18.0$ & 2.7 \\
\hline
\end{tabular}

Each value is presented as the mean \pm SD for 6 males in i) SHR, and 5 males in ii) SHR.

The feeding periods were 4 weeks for i) SHR, 8 weeks for ii) SHR.

${ }^{*} \mathrm{P}<0.05$ compared with the control rats in each group of water intake.

上昇せず, 分割添加の反応が終了した, 反応開始 17 時間 後のグルタミン酸変換率は $24.6 \%$ であった.

このように，カボチャ $150 \mathrm{~g}$ 分の粉碎液にグルタミン 酸 $15 \mathrm{~g}$ を添加して変換反応を行なった場合, グルタミ ン酸を分割添加すると $\mathrm{pH}$ を 5.0-6.0 の間に維持するこ とができ，グルタミン酸をほぼ $100 \%$ r-アミノ酪酸に変 換できた：この場合の反応後の水溶性成分凍結乾燥物の $\gamma$-アミノ酪酸含量は $36.3 \%$ と高濃度になっていた。

pHを 5.0-6.0 に維持した結果, 反応時間が短縮され, かっグルタミン酸変換率が高くなったのは，カボチャの グルタミン酸脱炭酸䣼素の補䣼素 PLP が保持され, 醉 素活性が維持されためと思われる.

なお今までの実験結果では, 最す酵素活性が高いカボ チャを使用して，最適条件下でグルタミン酸変換反応を 行なった場合，反応時間は 5 時間であった。

4. カゼイン加水分解物を使用した $\gamma$-アミノ酪酸高 含有素材の調製

前項において，カボチャ中の醉素を用いてグルタミン 酸を $\gamma-ア ミ /$ 酪酸に変換し， $\gamma-ア ミ ノ$ 酪酸を $35 \%$ 以上 の高濃度で含有する素材を製造する方法を確立した．こ の素材をデキストリン溶液で希釈して乾燥させ， $\gamma$-アミ ノ酪酸を $10 \%$ 含有する $\gamma-ア ミ$ ノ酪酸高含有素材を調製 し，これをカボチャ加工品 I とした．また同様に，グル タミン酸の代わりにカゼイン加水分解物（グルタミン酸 ナトリウムをグルタミン酸として $20 \%$ 含有）を使用し
て， $\gamma$-アミ/酪酸高含有素材を製造する方法を検討し た. カゼイン加水分解物を使用した場合，添加時の反応 液の $\mathrm{pH}$ 低下が起こらないため，基質は一度に添加し $\mathrm{pH}$ スタット法により $\mathrm{pH}$ を5.8に保持して反応を行 なった．その結果，カゼイン加水分解物中のグルタミン 酸のほぼ全量 $(98.3 \%)$ を $\gamma-ア ミ /$ 酪酸に変換するこ之 ができ，また，カボチャ粉砕液の反応後の水溶性成分凍 結乾燥物の $\gamma$-アミ，酪酸含量は $10.0 \%$ となった。（力ボ チャ加工品II）このように，グルタミン酸を含むカゼイ ン加水分解物を使用した場合でも，カボチャ中のグル夕 ミン酸脱炭酸䣼素を用いてグルタミン酸を $r-$ ア 酸に変換し， $\gamma$-アミ/酪酸高含有素材を製造することが できた。

5. $\boldsymbol{\gamma}$-アミ/酪酸高含有素材の血圧上昇抑制効果

上記の $\gamma$-アミ／酪酸高含有素材（カボチャ加工品 I 及 びII）を用いて，SHRに対する血圧上昇㧕制効果の確認 を行なった。

（1）食塩負荷 SHR 系雄ラットに対する血圧上昇抑制 効果

Table 8 に全実験期間中のラットの捸取量, 飲水量, 体重の変化を示した，摄取量, 体重の変化については各 群間に有意の差は認められなかった。しかし，飲水量に おいては食塩負荷により，いずれの群においても有意に 增加した. Table 9 に実験期間中の試験区 (試料供与群) ラット之対照区 (水供与群) ラットの血圧の変化を示し 
Table 9 Effect of the squash products on the blood pressure level in SHR dosed with $\mathrm{NaCl}$ and basal diet

\begin{tabular}{|c|c|c|c|}
\hline & \multicolumn{2}{|c|}{ Systolic blood pressure } & \multirow{2}{*}{$\begin{array}{c}\text { Rise in the systolic } \\
\text { blood pressure } \\
\text { (mmHg/28 days) }\end{array}$} \\
\hline & $\begin{array}{c}\text { Initial } \\
\text { (6 weeks old) } \\
\text { (mmHg) }\end{array}$ & $\begin{array}{c}\text { Final } \\
\text { (10 weeks old) } \\
(\mathrm{mmHg})\end{array}$ & \\
\hline \multicolumn{4}{|l|}{ i) $\mathrm{SHR}$} \\
\hline Control rats basal (CE-2) & $142 \pm 10.0$ & $185 \pm 8.6$ & $43 \pm 9.3$ \\
\hline CE- 2 containing $5 \% \mathrm{NaCl}$ & $142 \pm 6.8$ & $220 \pm 9.0^{* 1}$ & $78 \pm 7.9^{* 1}$ \\
\hline CE- 2 containing $5 \% \mathrm{NaCl}$ and $0.5 \%$ sample I & $142 \pm 7.4$ & $190 \pm 5.6^{* 1}$ & $48 \pm 6.5^{* 1}$ \\
\hline \multirow[t]{2}{*}{ CE- 2 containing $5 \% \mathrm{NaCl}$ and $0.5 \%$ sample II } & $142 \pm 9.6$ & $208 \pm 6.3^{* 1}$ & $66 \pm 8.0^{* 1}$ \\
\hline & $\begin{array}{l}\text { Initial } \\
\text { (7 weeks old }) \\
(\mathrm{mmHg})\end{array}$ & $\begin{array}{c}\text { Final } \\
\text { (15 weeks old) } \\
\text { (mmHg) }\end{array}$ & $\begin{array}{c}\text { Rise in the systolic } \\
\text { blood pressure } \\
\text { (mmHg/56 days) }\end{array}$ \\
\hline \multicolumn{4}{|l|}{ ii) SHR } \\
\hline Control rats $(\mathrm{CE}-2)$ & $184 \pm 8.5$ & $235 \pm 12.4$ & $51 \pm 10.5$ \\
\hline $\mathrm{CE}-2$ and $0.1 \%$ sample II & $184 \pm 8.2$ & $223 \pm 6.6^{* 2}$ & $39 \pm 7.4^{* 2}$ \\
\hline CE-2 and $0.1 \%$ sample III & $184 \pm 10.4$ & $235 \pm 9.3$ & $51 \pm 9.9$ \\
\hline
\end{tabular}

Each value is presented as the mean \pm SD for 6 males in i) SHR, and 5 males in ii) SHR.

${ }^{* 1} \mathrm{P}<0.05$ compared with the $\mathrm{CE}-2$ diet containing $5 \% \mathrm{NaCl},{ }^{* 2} \mathrm{P}<0.05$ compared with the CE-2 with $0.1 \%$ sample III.

た. 群分けした時点での平均血圧は試験区, 対照区の各 群共 $142 \mathrm{~mm} \mathrm{Hg}$ と同じであった. 試験を開始してから 4 週後の $5 \%$ 食塩含有 $\mathrm{CE}-2$, 水自由摄取群の血圧は対 照区（CE-2, 水自由摄取群）よりも $35 \mathrm{mmHg}$ の血圧上 昇か認められ，食塩の負荷が血圧上昇に影響を及代して いることが示された，一方， $5 \%$ 食塩含有 $\mathrm{CE}-2$ ，水自由 摄取群に対して, カボチャ加工品 I溶液自由摂取群では $30 \mathrm{~mm} \mathrm{Hg}$, カボチャ加工品I溶液自由摂取群では 12 $\mathrm{mm} \mathrm{Hg}$ の血圧上昇抑制が認められた。 カボチャ加工品 I 溶液自由摂取群と比較して, カボチャ加工品几溶液自 由摄取群では，血圧上昇抑制が半分以下であった，カボ 千ャ加工品Iにはカゼイン加水分解物由来の食塩が多く 含まれているが (Table 1), 飼料由来の食塩と比較する と約 200 分の 1 之微量であるため, 血圧への影響は無視 できると思われる. 従って, カボチャ加工品I 上比較し

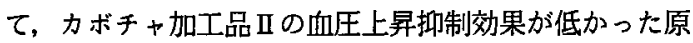
因は，カボチャ加工品 I中の食塩以外の成分と考えられ た.

なお, 臓器重量, 臓器所見, 及び臓器中の遊離アミノ 酸含量は各試験区の間に顕著な差は認められなかった。

(2) SHR 系雄ラットに対する血圧上昇抑制効果

Table 9 に実験期間中の試験区（カボチャ加工品I溶 液供与群）と対照区（水供与群, カボチャ加工品亚溶液
供与群）の血圧の変化を示した．群分けした時点での平 均血圧は試験区, 対照区の各群共 $184 \mathrm{~mm} \mathrm{Hg}$ 之同じで あった．試験を開始してから 8 週間後の対照区の水供与 群およびカボチャ加工品项溶液供与群の血圧は $235 \mathrm{~mm}$ $\mathrm{Hg}$ と同一であり, カボチャ加工品 II 溶液供与群では $223 \mathrm{~mm} \mathrm{Hg}$ と, $12 \mathrm{~mm} \mathrm{Hg}$ の血圧上昇抑制が認められ た.

カボチャ加工品Ｉには血圧上昇抑制勃果が認められた が，力ボチ+加工品 II とは $\gamma$-アミ，酪酸含量以外の成分 組成が等しいカボ千ャ加工品亚には血圧上昇抑制効果が 認めらなかったことから，カボチャ加工品によるラット の血圧上昇抑制効果は，力ボチャ加工品中の $\gamma$-アミノ酪 酸が主として作用していることが示唆された。しかしな がら，力ボチャ加工品历の製造工程では，力ボチャ中の グルタミン酸脱炭酸醅素が中心に作用しているが，カボ チャ粉碎液を用いていることから，一部副産物が生成し ていることも考えられ，この点については検討が必要と 思われる.

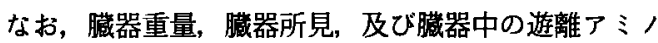
酸含量は各試験区の間に顕著な差は認められなかった。

$$
\text { 要 約 }
$$

グルタミン酸脱炭酸醉素は動植物界に広く存在する醉 
素であり, 高等植物ではカボチャ, キュウリ，ニンジン， トマトなどに多く含まれる.これらの高等植物の中で は, カボチャが最もグルタミン酸脱炭酸酵素活性が強い ことがわかり，カボチャのグルタミン酸脱炭酸酵素活性 を利用した $\gamma-ア ミ ノ$ 酪酸高含有素材の製造法を検討し た.

カボチャによるグルタミン酸の $\gamma$-アミノ酪酸への変 換反応では，グルタミン酸脱炭酸醉素の補醉素であるピ リドキサル $5^{\prime}$ ーりん酸が， $\gamma$-アミ／酪酸生成量に影響し ていることがわかった．また， $\gamma$-アミ/酪酸生成の最適 な温度, $\mathrm{pH}$ 等の条件について検討した結果，カボチャ とグルタミン酸だけで，10\%以上と高含有量の $\gamma$-アミ 八酪酸を力ボチャに付加することができた。このカボ チャ粉砕液の水溶性成分を乾燥したカボ千ャ加工品に は, 高血圧自然発症ラット（SHR）に対する血圧上昇抑 制効果があることを確認した。

\section{文献}

1) Takahashi, H., Sumi, M. and Koshino, F. : Jpn. J. Physiol., 11, 89 (1961).

2）塚田裕三：日本医師会雑誌，42，8，55（1959）.

3）岡田忠司，杉下朋子，村上太郎，村井弘道，三枝 貴代，堀野俊郎，小野田明彦，梶本修身，高橋
励，高橋丈夫，食科工，47，8，596（2000）.

4）林 智, 斉藤ひろみ，大森正司，猪股智夫，加 藤みゆき，澤井祐典，深津修一，袴田勝弘，家政 誌，51，4，265（2000).

5）津志田藤二郎，村井敏信，大森正司，岡本順子， 農化, 61，7，817 (1987).

6）中川紀代司，小野田明彦，食品之開発，31，9，43 (1996).

7）農林水産省中国農業試験場長，特許第 2590423 号 (1996).

8) Saikusa, T., Horino, T. and Mori, Y., J. Agric. Food Chem., 42, 1122 (1994).

9）農林水産省食品総合研究所長 : 特許第 2891296 号 (1999).

10）宮間浩一・岡本竹己，栃木県食品工業指導所研究 報告，14，10（2000）。

11）松本恭郎，大野一仁，平岡芳信，愛媛県工業技術 センター研究報告, No. 35 (1997).

12) Matsumoto, T., Yamaura, I. and Funatsu, M., Biosci. Biotech. Biochem., 60, 5, 889 (1996).

13）実験動物の飼育及び保管等に関する基準，総理府 告示第 6 号, 栄食誌, 54, 68 (2001).

14) Matsumoto, T., Yamaura, I. and Funatsu, M., Agric. Biol. Chem., 50, 6, 1413 (1986).

（平成 13 年 11 月 2 日受付, 平成 14 年 6 月 25 日受理） 